Arq. Bras. Med. Vet. Zootec., v.68, n.3, p.658-666, 2016

\title{
Insertion of the LINE-1 element in the C-MYC gene and immunoreactivity of C-MYC, p53, p21 and p27 proteins in different morphological patterns of the canine TVT
}

\author{
[Inserção do elemento LINE - 1 no gene C-MYC e imunorreatividade das proteinas C-MYC, \\ p53 , p21 e p27 nos diferentes padrões morfológicos do tumor TVT] \\ C.R.O. Lima $^{1}$, M.B.R. Faleiro ${ }^{2}$, R.E. Rabelo ${ }^{3}$, V.A.S. Vulcani ${ }^{3}$, \\ M.R. Rubini ${ }^{4}$, F.A.G. Torres ${ }^{4}$, V.M.B.D. Moura ${ }^{2}$. \\ ${ }^{1}$ Universidade Estadual de Goiás - UEG - Goiânia, GO \\ ${ }^{2}$ Universidade Federal de Goiás - UFG - Goiânia, GO \\ ${ }^{3}$ Universidade Federal de Goiás - UFG - Regional Jataí Goiânia, GO \\ ${ }^{4}$ Universidade de Brasília - UNB - Brasília, DF
}

\begin{abstract}
The canine transmissible venereal tumor (TVT) affects the external genitalia of dogs by the natural transplant of viable tumor cells. Thus, this research aimed to diagnose and characterize TVT morphological patterns, identify the insertion of the LINE-1 element in C-MYC gene, by means of the polymerase chain reaction (PCR), and evaluate the immunohistochemical expression of C-MYC, p53, p21 and p27 proteins. The relationship between C-MYC and p53 proteins and their interference on the expression of p21 and p27 were also studied. For that, 20 samples of naturally occurring TVT were used, subjected to cytopathological, histopathological and immunohistochemical analysis, and to molecular diagnosis of neoplasia. The increased tissue expression and the correlation among C-MYC, p53, p21 and p27 proteins indicate reduction and/or loss of their functionality in the TVT microenvironment, with consequent apoptotic suppression, maintenance of cell growth and progression of neoplasia.
\end{abstract}

Keywords: dog, cell , cytology, immunohistochemistry

\section{RESUMO}

O tumor venéreo transmissível canino (TVT) afeta a genitália externa de cães pelo transplante natural de células tumorais viáveis. Assim, esta pesquisa teve como objetivo diagnosticar e caracterizar TVT em padrões morfológicos, identificar a inserção do elemento LINE-1 em gene C-MYC, por meio da reação em cadeia da polimerase (PCR), e avaliar a expressão imuno-histoquímica do C-MYC, p53, p21 e p27. A relação entre C-MYC e as proteínas p53 e a sua interferência na expressão de p21 e p27 foram também estudadas. Para isso, foram utilizadas 20 amostras de ocorrência natural de TVT, submetido a exame citopatológico, histopatológica e imuno-histoquímica e ao diagnóstico molecular de neoplasia. A expressão aumentada do tecido e a correlação entre a C-MYC e as proteínas p53, p21 e p27 indicam redução elou perda de funcionalidade na TVT em seu microambiente, com consequente supressão apoptótica, manutenção do crescimento celular e progressão da neoplasia.

Palavras-chave: cão, celular, citologia, imuno-histoquímica

\section{INTRODUCTION}

The canine transmissible venereal tumor (TVT) has unique features. Since it is not originated from the neoplastic transformation of normal cells, its growth and evolution occur as a result

Recebido em 12 de julho de 2015

Aceito em 14 de dezembro de 2015

E-mail: carolrochavet@hotmail.com of transmitting a clone of tumor cells from affected dogs to healthy ones. It is characterized as a round cell neoplasia, with single core and vacuolated cytoplasm (Amaral et al., 2012). Nevertheless, there are differences among cells that enable the classification of TVT according to a morphological, lymphocytoid, plasmacytoid or mixed pattern (Floréz et al., 2012). 
The insertion of the LINE-1 element in the CMYC gene refers to a specific molecular rearrangement of TVT. Thus, its identification is described as a complementary diagnostic method of neoplasia, and the polymerase chain reaction (PCR) consists of a highly specific molecular tool to verify that change (Fonseca et al., 2012).

The C-MYC gene is an aproto-oncogene regulator of the cell cycle with activity in different molecular pathways (Faria and Rabenhorts, 2006). Thus, in one of its regulatory pathways, C-MYC inhibits the function of p27 kinase inhibitor protein. It is speculated that this gene also interferes on the inhibition of tumor suppressor genes such as p21, p57, p15 and p16. C-MYC also acts triggering apoptotic mechanisms by the indirect activation of the p53 tumor suppressor gene, through p19 (Pelengaris et al., 2003).

P53 protein has an antagonistic function to $\mathrm{C}$ MYC proteins, because it acts on check points activating tumor suppressor genes such as p21, which blocks the progression of the cycle (Sánchez-Servín et al., 2009). Although the p53 expression is described in TVT cells, there are no reports about this relationship, as well as C-MYC proteins, with those inhibiting the cell cycle and dependent on kinases (Moro et al., 2010).

This study aimed to diagnose and characterize TVT morphological patterns by cytopathological and histopathological examinations, identify the insertion of the LINE-1 element in the C-MYC gene through the polymerase chain reaction (PCR), the immunohistochemical expression of C-MYC on coprotein and p53, p21 and p27 tumor suppressor proteins and the interference of $\mathrm{C}-\mathrm{MYC}$ and $\mathrm{p} 53$ proteins in the $\mathrm{p} 21$ and $\mathrm{p} 27$.

\section{MATERIALS AND METHODS}

The research was approved by the Comite de Ética em Pesquisa of the Universidade Federal de Goiás under protocol number 123/11. Twenty dogs affected by naturally occurring TVT were used, with no restriction of age, gender and breed, not undergoing prior chemotherapy and with a tumor located primarily on external genitalia. In order to obtain clinical data, the animals were subjected to complete physical examination and the information was recorded in individual clinical evaluation protocols.
A biopsy fragment was obtained from every tumor, which, after resection, was sectioned into three fragments used for the preparation of the cytopathological sample (AT1), histopathological and immunohistochemical analyses (AT2), and molecular diagnosis of TVT (AT3). In order to compose the negative control group of the molecular diagnosis of TVT, a sample from a second neoplastictype (mastocytoma) and two samples of peripheral blood from healthy animals were obtained. Three milliliters of whole blood were collected from those samples, being packed in vacutainer tubes with EDTA (Becton, Dickinson \& Company, USA), and frozen at $20^{\circ} \mathrm{C}$ for DNA extraction and molecular analysis.

For cytopathological analysis, the samples obtained by the imprinting of the AT1 fragment were fixed in methanol for $5 \mathrm{~min}$ and subjected to Giemsa staining for 30min. The cytomorphological diagnosis of TVT was established according to Cowell et al. (2008). Four-micrometer histological sections were made from the AT2 fragment included in paraffin, and then, they were distended on histological slides and stained by Hematoxylin and Eosin (HE). The histomorphological evaluation of TVT followed the criteria by Santos et al. (2008).

The samples evaluated in the cytopathological and histopathological analyses were also used for the classification of the predominant morphological pattern of TVT and followed the criteria proposed by Floréz et al. (2012). The apoptotic index of TVT was evaluated in histological slides stained by $\mathrm{HE}$, according to methodology adapted from Gonzalez et al. (2000). The parameter was estimated according to the discrete, moderate or sharp scores.

The immunohistochemical analyses were subjected to the tissue microarray (TMA) technique, according to the descriptions by Kononen et al. (1998) and Bubendorf et al. (2001). Mouse anti-human C-MYC Ab-2 monoclonal antibody, clone 9E10.3 (Thermo Fisher ScientificNeomarkers, MS-139-P0) were used, diluted at 1:50; mouse anti-human p53 monoclonal antibody, clone DO-7 (Dako M7001), diluted at 1:500; mouse anti-human

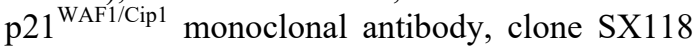
(Dako M7202), diluted at 1:50; and mouse antihuman and $\mathrm{p} 27^{\mathrm{Kip} 1}$ monoclonal antibody, clone SX53G8 (Dako M7203), diluted at 1:200. Then, 
protein blocking was conducted (Post Primary Block, Novo Link Max Polymer RE7260-K, United Kingdom) and the incubation was done in signal amplification system (Novo link Polymer, Novo Link Max Polymer RE7260-K, United Kingdom).

For the visualization of the reaction, the sections were submerged in diaminobenzidine (DAB) solution (100mg of 3.3'diaminobenzidine tetrahydrochloride, (Sigma, D-5637, USA), $1 \mathrm{~mL}$ of dimethylsulfoxide (DMSO), $1 \mathrm{~mL}$ of $\mathrm{H}_{2} \mathrm{O}_{2} 20$ volumes at $6 \%$ and $100 \mathrm{~mL}$ of PBS buffer), away from the light. Following, the sections were washed, stained with Harris hematoxylin, diaphanized and mounted with coverslipand synthetic resin (Entellan, Merck, 1.07961, Germany). As positive control of the reactions, samples of human breast carcinoma (C-MYC), canine squamous cell carcinoma (p-53) and

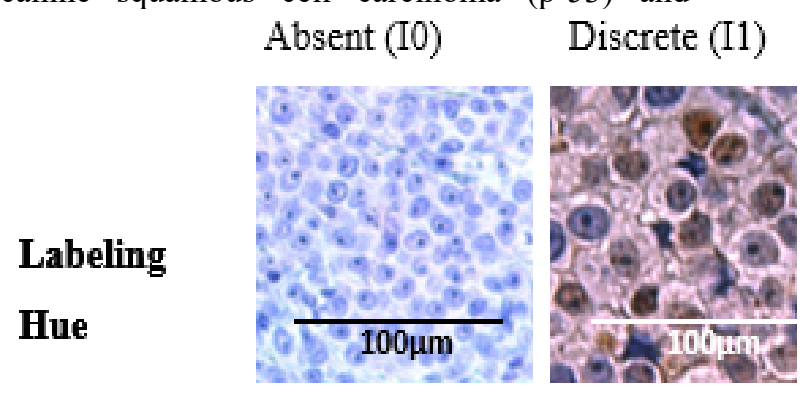

human colon carcinoma (p-21 and p-27) were used. For the negative control of the reactions, a $10 \mathrm{mMpH} 7.4$ PBS buffer solution was used to substitute the primary antibodies.

In an optical microscope, TMA slides were evaluated regarding immunolabeling, following the analysis of the intensity (I) of labeling according to (I0) absent, (I1) discrete, (I2) moderate and (I3) sharp scores (Fig. 1). The percentage (C) of immunolabeled cells in every TVT morphological pattern was also measured, in order to evaluate the correlation between $\mathrm{C}$ MYC and p53, C-MYC and p21/p27, and p53 and $\mathrm{p} 21 / \mathrm{p} 27$ proteins. For that, the scores (C0) absence of immunolabeled cells, (C1) immunolabeling of $1-25 \%,(\mathrm{C} 2)$ of $26-50 \%,(\mathrm{C} 3)$ of $51-75 \%$ and $(\mathrm{C} 4)$ of $76-100 \%$ of the cells were considered.

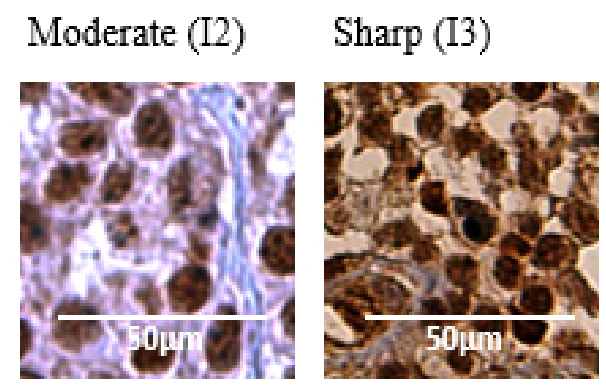

Figure 1. Staining intensity scores assigned to the labeling analysis in C-MYC, p53, p21 ${ }^{\text {WAF1/Cip1 }}$ and $\mathrm{p} 27^{\mathrm{Kip} 1}$ antibodies in canine TVT.

The extraction of genomic DNA from positive samples and negative control of TVT, as well as the analyses for the molecular identification were conducted according to the descriptions by Fonseca et al. (2012). The samples were evaluated regarding the presence of the molecular rearrangement of the LINE-1 element in the C-MYC gene, by the PCR technique. For that, the primers MYC.S, LINE.A, HBGA.S and HGBA.A were used. The reaction obtained from the HBGA.S and HGBA.A primers, which amplifies a $480 \mathrm{pb}$ segment of the human hemoglobin gene, composed the internal positive control of the PCR.

The reaction was composed of different elements and concentrations, being $0.2 \mu \mathrm{m}$ of every primer, $0.2 \mathrm{mMof}$ dNTPs solution, polymerase TaqDNA buffer for a final concentration of $1 \mathrm{X}, 2 \mathrm{U}$ of polymerase TaqDNA, magnesium chloride in optimum concentration for every pair of primer and approximately 10ng of genomic DNA and $\mathrm{H}_{2} \mathrm{O}_{2}$ enough to make up a final volume of $25 \mu \mathrm{L}$. The amplification reaction was performed in a Swift MaxPro SWT thermal cycler (ESCO MICRO Pte LTD.), programmed to perform a sequential protocol consisting of a denaturation cycle at $94^{\circ} \mathrm{C} / \mathrm{min}$. After the end of the PCR procedure, the gel was stained with $0.3 \mu \mathrm{g} / \mathrm{mL}$ of ethidium bromide and analyzed by electrophoresis in 1\% agarose gel.

The data relating to the diagnosis, the morphological classification, the identification of the LINE-1 element in the C-MYC gene, the expression and the intensity of C-MYC, p53, p21 and p27 immunolabeling were analyzed descriptively. For the correlation analysis of the immunolabeling percentage between C-MYCand p53 proteins, as well as among C-MYC, p21, and p27 and among p53, p21, and p27, the nonparametric test of Spearmann was applied with the significance level of $5 \%(\mathrm{P} \leq 0.05)$. 


\section{RESULTS}

The cytopathological analysis enabled better characterization of the cell type, with lower image distortion when compared to histopathological analysis. Therefore, the predominant morphological pattern of TVT (Figure 2) was established by cytopathological analysis, observing predominance of the plasmacytoid type, with nine cases $(45 \%)$ of the total of the samples analyzed. The second most common type was the lymphocytoid, observed in six cases $(30 \%)$, followed by the mixed type in five cases $(25 \%)$ of the total of tissues examined. The apoptotic TVT index was discrete in $100 \%$ of the samples analyzed.

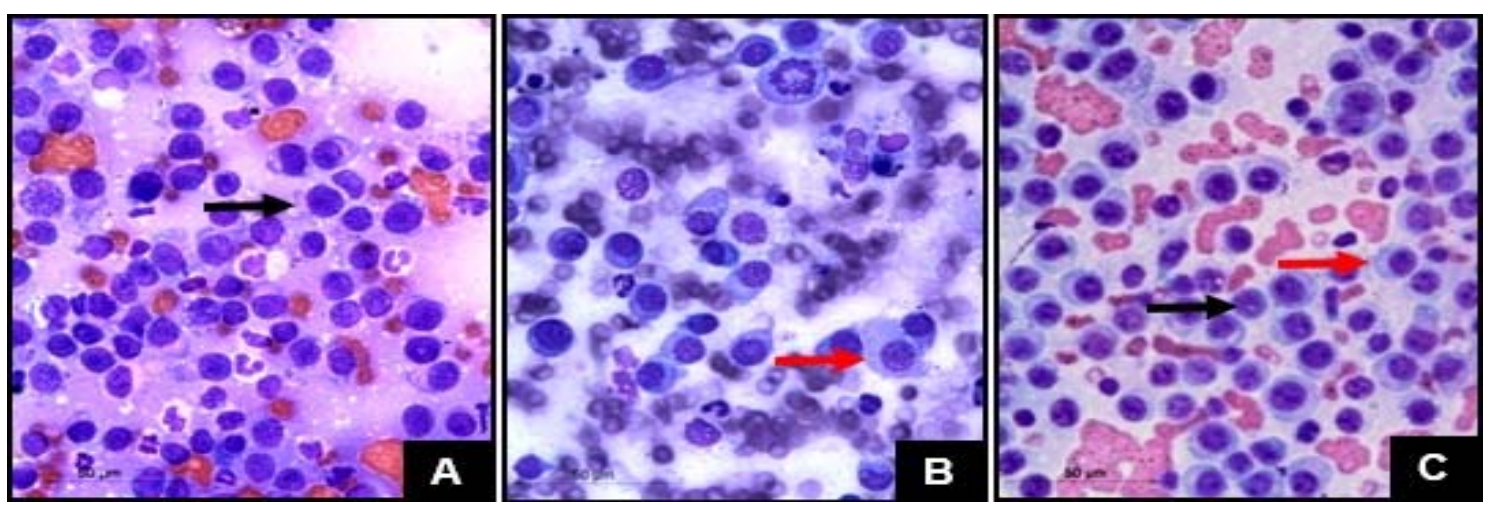

Figure 2. Photomicrographs of morphological patterns of canine TVT cells by cytopathological examination. (A) The Lymphocytoid pattern. Round cells, with large nuclei and scant cytoplasm, similar to lymphocytes (black arrow). (B) Plasmacytoid pattern. Cells with more abundant cytoplasm and eccentric nuclei, with lower nucleus/cytoplasm ratio (red arrow). (C) Mixed pattern. Lymphocytoid (black arrow) and plasmacytoid (red arrow) morphology cells. Giemsa, 400x.

In Figure 3, the molecular rearrangement of the LINE-1 element in the C-MYC gene is identified, used for the complementary diagnosis of TVT. The genomic DNA of the canine transmissible neoplasia, columns 1 to 19 , amplified a fragment of approximately $340 \mathrm{pb}$ that characterizes the LINE-1/C-MYC molecular rearrangement, and a second fragment with an approximate molecular weight of $480 \mathrm{pb}$, from the human hemoglobin gene, which represents the internal positive control of the reaction. Columns 20, 21, 22 and 23 represent the negative control group. The amplification of a segment of the genomic DNA of mastocytoma, the second neoplastic type considered in the study, is shown in column 20. Only the fragment of approximately $480 \mathrm{pb}$ was amplified, with total absence of amplification regarding the $340 \mathrm{pb}$ band (light blue arrow). Columns 21 and 22 refer to the analysis of the amplification of DNA from whole blood samples of healthy dogs. Column 21 represents the absence of amplification of the LINE1/C-MYC rearrangement (yellow arrow). Column 22 shows the reaction between the blood samples and the human hemoglobin gene (red arrow). Column 23 (green arrow) represents the internal negative control of the PCR, with total absence of amplification, due to the absence of DNA.

The immunohistochemical analysis showed labeling for C-MYC, p53, p21, and p27 proteins in $100 \%$ of the samples, regardless of the morphological pattern of TVT (Figure 4). However, variation in immunolabeling was observed when the intensity scores for the lymphocytoid, plasmacytoid, and mixed types were applied. For C-MYC protein, the scores were I2 and I3 in the lymphocytoid type, with no predominance of either of them. In the case of plasmacytoid and mixed patterns, there was predominance of the I3 score. For p53, the I1, I2 and I3 scores were observed on the lymphocytoid type, also with no predominance of any score. In the case of plasmacytoid, the predominant score was the I2, followed by I3 and $I 1$, respectively, and, in the mixed, the labeling score was I3 in all samples. The intensity of p21 in the lymphocytoid and plasmacytoidtypes was predominantly I3 score, followed by I2 and I1, while, in the mixed type, the score was I3. As for the p27, the intensity was I2 and I3 in the lymphocytoid type and I3 in the plasmacytoid and mixed types. 

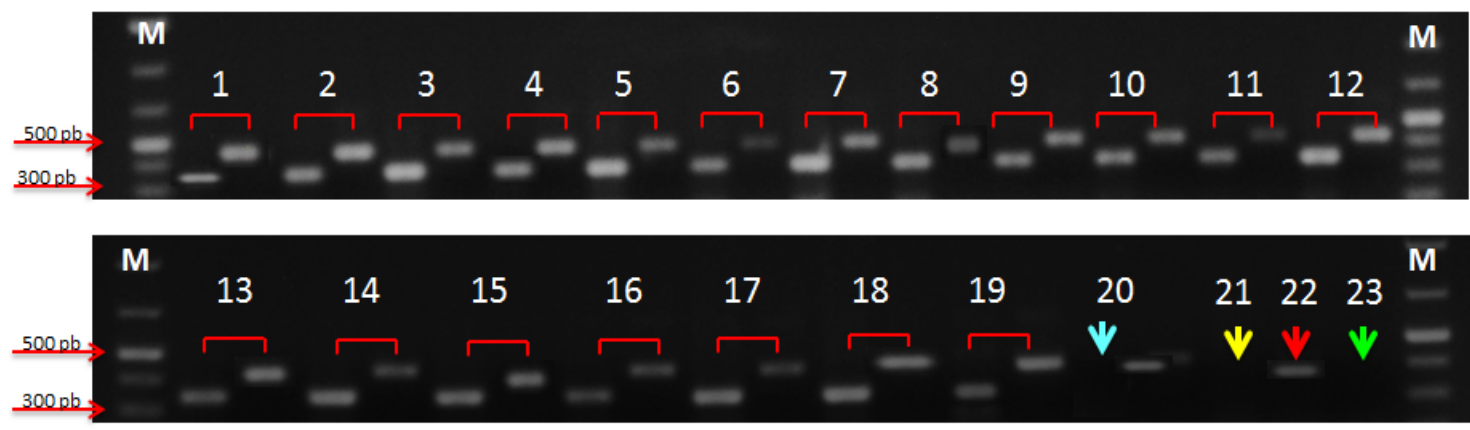

Figure 3. Molecular diagnosis of canine transmissible venereal tumor (TVT) by the polymerize chain reaction (PCR). Column M - molecular weight marker Ruler 1kb Plus Gene. Columns 1 to 19 - product of the amplification from the genomic DNA of TVT. Column 20 demonstrates the amplification of the genomic DNA of the mastocytoma, represented by the light blue arrow. Columns 21 and 22 represent the amplification of the DNA in whole blood samples of healthy dogs, marked with the yellow and red arrows, respectively. Column 23 (green arrow) represents the internal negative control of the PCR (absence of DNA).
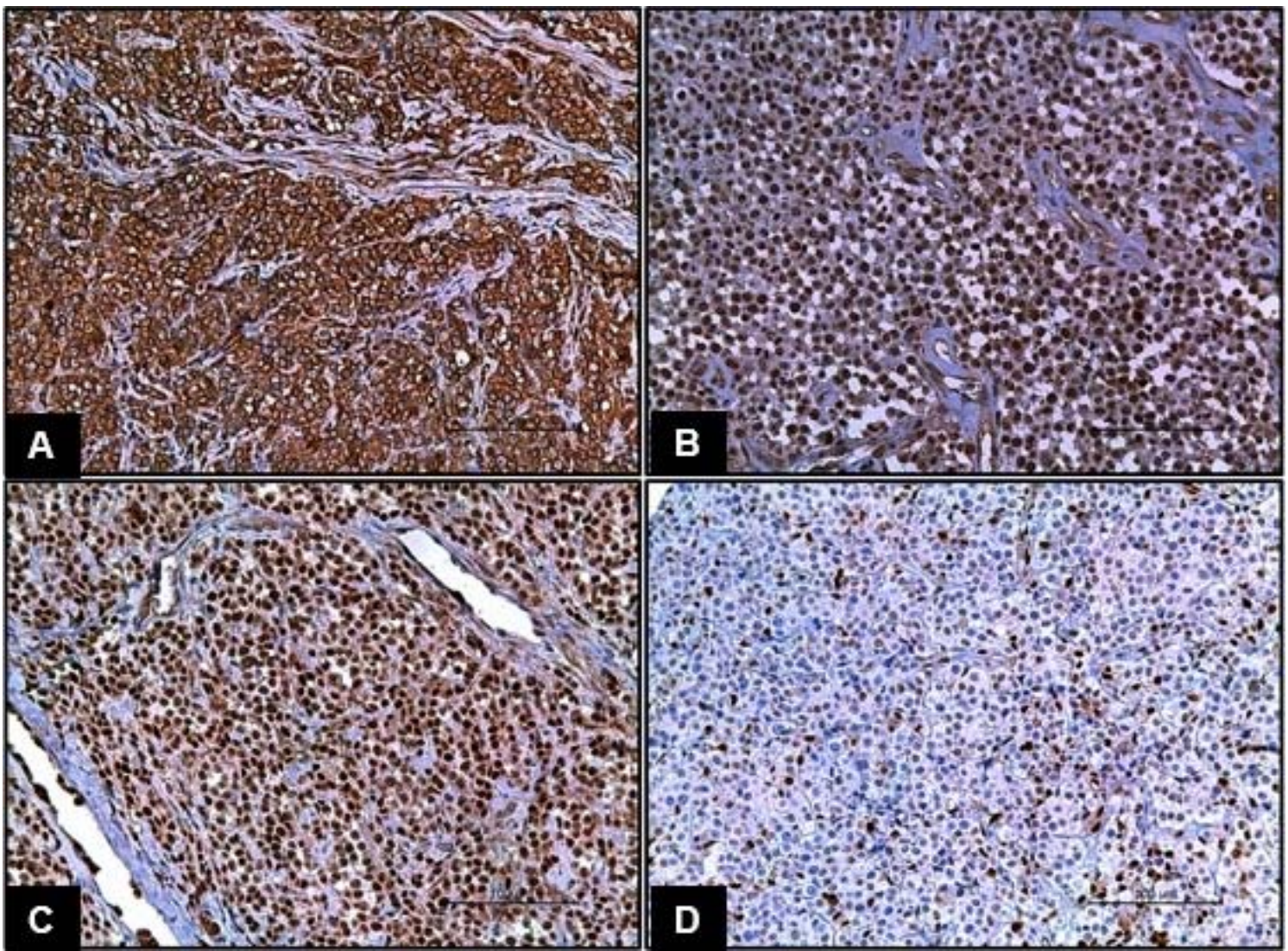

Figure 4. Photomicrographs of immunohistochemical reactions in canine TVT. (A) C-MYC. Cytoplasmic labeling in $\mathrm{I} 3$ and $\mathrm{C} 4$ scores for labeling intensity and percentage of labeled cells. (B) p53. Nuclear labeling in the I3 and C4 scores for labeling intensity and percentage of labeled cells. (C) p21. Nuclear labeling in the $\mathrm{I} 2$ and $\mathrm{C} 4$ scores for labeling intensity and percentage of labeled cells. (D) p27. Nuclear labeling in the 2 and $\mathrm{C} 1$ scores for labeling intensity and percentage of labeled cells. IHC, 250x. 
As for the immunolabeling percentage of every protein in the morphological patterns of TVT, there was maximum expression $(\mathrm{C} 4)$ of $\mathrm{C}-\mathrm{MYC}$ and p53 in the lymphocytoid, plasmacytoid and mixedtypes. For p21, there was predominance of the $\mathrm{C} 2$ score, followed by $\mathrm{C} 3$ and $\mathrm{C} 4$, both for the lymphocytoid and the plasmacytoid types. On the mixed type, there was a predominance of $\mathrm{C} 2$, followed by $\mathrm{C} 3$. Regarding the $\mathrm{p} 27$, there were $\mathrm{C} 2$ scores, followed by $\mathrm{C} 3$ and $\mathrm{C} 1$ in the lymphocytoid type. In the plasmacytoid, there was predominance of $\mathrm{C} 1$, followed by $\mathrm{C} 2$ and $\mathrm{C} 3$, while in the score there was the $\mathrm{C} 3$ score, followed by $\mathrm{C} 2$.

In the correlation analysis, there was correlation in the percentage of immunolabeled cells between $\mathrm{C}-\mathrm{MYC}$ and $\mathrm{p} 53$ proteins $(\mathrm{P}>0.05)$ for all morphological patterns of TVT. The results of the analyses of correlation among C-MYC, p21, and p27 and among p53, p21, and p27 proteins demonstrate correlation $(\mathrm{P}>0.05)$ for most of the proteins considered, except in the analysis among p53, p21, and p27 with plasmacytoid morphology.

\section{DISCUSSION}

In this research, the plasmacytoid type occurred most frequently, followed by the lymphocytoid and mixed types, respectively. Similar results were described by Amaral et al. (2007) and Gaspar et al. (2010), who found greater occurrence of the plasmacytoid pattern in the genital samples and also in the primary or metastatic extra genital samples.

PCR results prove the high sensitivity of the test for the detection of rearrangement of the LINE-1 element in the C-MYC gene in TVT, since all the samples of the transmissible neoplasia studied amplified a fragment of approximately $340 \mathrm{pb}$, which characterizes such rearrangement, corroborating the observations by O'Neill (2011). It should be highlighted that there was no amplification in the other samples considered in this study. Although Spin et al. (2010) have confirmed that this change is characteristic of TVT when compared to the analysis of this same rearrangement in the blood of healthy animals, they did not mention if such occurrence is specific for this neoplastic type. However, the absence of the LINE-1/C-MYC molecular rearrangement in a canine mastocytoma sample of this study suggests that such molecular change is specific to TVT.

The MYC.S and LINE.A primers prepared for this research were specific for the identification of the amplification of a DNA fragment including approximately $340 \mathrm{pb}$, being in accordance with the methodology by Spin et al. (2010) and Fonseca et al. (2012). However, it differed from the results presented by other authors like Park et al. (2006), who identified a $550 \mathrm{pb}$ amplification responsible for the formation of the LINE-1/C-MYC rearrangement in TVT. Since the LINE-1 element has a sequence of $1,378 \mathrm{pb}$ inserted into the C-MYC gene, the differences in amplifications are justified by virtue of the use of primers that configure different gene regions in this rearrangement (Murchison, 2009).

Although Andrade et al. (2007) have mentioned the concern about the reduced area of the samples in the representativeness of important and decisive findings concerning the technique to process the samples for immunohistochemical analysis, the TMA, in this study, such method enabled the analysis of the different labels, with lower cost, and greater agility, not affecting the accuracy of the results.

Considering the criterion of immunolabeling intensity, in which the fraction of the labeled cell area is evaluated (Matos et al., 2006), it is possible to state that C-MYC, p53, p21, and p27 proteins are present in all TVT samples. In this context, despite the variation of immunolabeling intensity among proteins, it was subtle among the different morphological patterns of TVT.

On the other hand, the immunolabeling quantification, given by the analysis of the cell labeled percentage compared to the total of cells in the sample, enables the finding of the level of tissue accumulation in those proteins and evaluates the interactions among them. It also enables the indirect recognition of the possible mechanisms involved in the growth and progression of neoplasia. Matos et al. (2006) and Trompieri-Silveira et al. (2009) also adopted the immunolabeling percentage parameter to quantify immunolabeled cells for different proteins. In that sense, Trompieri-Silva et al. (2009), considering the percentage of labeled cells, compared the variation of the 
immunolabeling of the anti-CD3 antibody among the progression and regression phases of TVT, and there were differences in the amount of $\mathrm{T}$ lymphocytes in those phases.

The over expression of the C-MYC protein in all morphological types of TVT, represented by the C4 score of the percentage of labeled cells, can be attributed to the occurrence of mutation of the C-MYC gene, initially, by the occurrence of the molecular rearrangement proven by the PCR technique. According to Faria and Rabenhorts (2006), differentiated cells express low levels of C-MYC, due to their short half-life. Thus, it is suggested that the change in the C-MYC gene implies the synthesis of changed protein, with reduction or absence of its function and accumulation in the neoplastic tissue. This protein mutation would assist the maintenance of cell growth and the tumor progression, once the C-MYC, when functional, acts on the tissue integrity inducing the cell apoptosis from different pro-apoptotic pathways, including the indirect activation of BAX and p53 proteins, as well as the connection with the CD95/FAS receptor. At the same time, under normal conditions, the C-MYC acts on cell proliferation, inhibiting the transcription of p21 and p27, however, its stimulus ceases when the process is completed, in order to avoid the continuous stimulus and the resulting disordered cell proliferation (Faria and Rabenhorst, 2006, pp. 165-171).

P53 protein showed a behavior similar to that of C-MYC, with over expression (C4) in all morphological patterns of TVT. Sánchez-Servín et al. (2009) showed polymorphisms in different places of P53 gene in TVT samples. In that context, although the molecular analysis of P53 was not applied in this research, it is believed that possible gene mutations are the cause of the changes in the conformation of the protein, leading to increased half-life, occasional function loss and accumulation in cells, as described by Calazans et al. (2010) and Lima et al. (2012a). In the same way, Santos et al. (2008) and Moro et al. (2010), while investigating the functional impairment of the p53 protein by immunohistochemistry, suggested that the immunolabeling pattern found indicates functional abnormality in p53 and in the protein formed from the transcription of the abnormal gene, although they have not been able to correlate the percentage of labeled cells to the prognosis of TVT.

The correlation analysis between C-MYC and p53 proteins were conducted in order to investigate the interaction between them, potentially changed, and the ability of inactivation or expression, respectively, of p21 and p27 tumor suppressor proteins, in different TVT cell types.

The relationship between C-MYC and p53, as described by Stockmann et al. (2011), is associated with the induction of cell apoptosisrelated pathways. Although the statistical analysis has confirmed the correlation, in this study, there were no morphological changes that could characterize the apoptosis. This fact supports the hypothesis of dysfunction of CMYC and p53 proteins, with consequent maintenance of cell growth and progression of TVT. Despite the description of apoptosis on TVT (Moro et al., 2010), no information was found about the impairment of the apoptotic mechanism related to the dysfunction of the CMYC protein. On the other hand, Santos et al. (2008) studied the apoptosis in TVT by evaluating the integrity of p53 in experimentally transplanted tumors and found that, during tumor regression, the p53 expression was higher if compared to the progression phase. The authors also explain that the higher expression was related to the apoptosis of neoplastic cells. On the other hand, considering the findings of this study, it is possible that the protein functions have distinct behaviors in tumors experimentally transplanted and in those naturally acquired. This suggests that the naturally occurring ones have higher aggressive potential, because, in those cases, the immune system is blocked by the immunophase phenomenon and the tumor cells remain in the progression phase longer, and they may even evolve to metastasis (Dunnet al., 2004).

The functionality of C-MYC was also measured based on the evaluation of its correlation with p21 and p27 proteins. The importance of that correlation is justified because of the impact of C-MYC for the control of the continued progression of the cell cycle, as mentioned by Lutz et al. (2002), by the functional inactivation of p21 and p27 proteins, which act blocking the progression of the cell cycle by inhibiting the 
cyclin-dependent kinases. The correlation among $\mathrm{C}-\mathrm{MYC}, \mathrm{p} 21$, and p27 proteins, observed in this study, enables the suggestion that the changes in the gene/C-MYC protein set may impair the inhibition mechanism of p21 and p27 tumor suppressor proteins, maintaining the growth of tumor cells and the progression of neoplasia continuously and disorderly. However, no information was found disagreeing or supporting this hypothesis.

Moreover, the correlation among p53, p21, and p27 proteins may have contributed to the immunolabeling profile of those last two proteins in the neoplastic tissue. However, despite the presence of those tumor suppressor proteins, there was no blocking to the growth of neoplastic cells. In that sense, it is speculated that the cell growth can also be related to an intrinsic mechanism developed by neoplastic cells, mediated by C-MYC, for the disorderly proliferation, those cells being responsive to new stimuli, whether for the growth or blocking of the cell cycle, as reported by Alboran et al. (2011). Furthermore, considering the tissue accumulation, the functionality of p21 and p27 proteins may also be impaired in TVT samples.

On the other hand, the absence of demonstrated correlation between $\mathrm{p} 53$ and $\mathrm{p} 21$ proteins in the TVT plasmacytoid type allows the inference of greater tendency to the progression of neoplastic cells, due to the absence of blocking in the cell cycle induced by this molecular pathway. Studies by Gaspar et al. (2010) and Amaral et al. (2012) refer to the higher aggressiveness of the plasmacytoid type of TVT in studies verifying the therapeutic response, the resistance to $p$ glycoprotein and the higher concentration of injuries to the DNA molecule, respectively. Thus, it is suggested that, in the plasmacytoid morphological pattern, molecular and protein changes are more expressive, culminating in the disruption of the p21 induction pathway mediated by $\mathrm{p} 53$.

\section{CONCLUSIONS}

The morphological TVT differences enable the classification of neoplasia concerning the predominant cell type in lymphocytoid, plasmacytoid or mixed types. The insertion of the LINE1 element in the C-MYC gene characterizes the specific molecular change in canine TVT, and the evaluation of this molecular rearrangement is useful for the complementary diagnosis in cases of undifferentiated TVT. The augmented tissue expression and the correlation among C-MYC, p53, p21, and p27 proteins indicate reduction and/or loss of their functionality in the TVT microenvironment, with consequent apoptotic suppression, maintenance of cell growth and progression of neoplasia.

\section{REFERENCES}

ALBORAN, I.M.; O'HAGAN, R.C.; GARTNER, F. et al. Analysis of C-MYC function in normal cells via conditional genetargeted mutation. Immunity, v.14, p.45-55, 2011.

AMARAL, A.V.C.; OLIVEIRA, R.F.; SILVA, A.P.S.M. et al. Tumor venéreo transmissível intraocular em cão: relato de caso. Vet. Zootec., v.19, p.79-85, 2012.

AMARAL, S.A.; BASSANI-SILVA, S.; FERREIRA, I. et al. Caracterização citomorfológica do tumor venéreo transmissível canino. Rev. Port. Ciênc. Vet., v.102, p.253-260, 2007.

ANDRADE, V.P.; CUNHA, I.W.; SILVA, E.M. et al. Tissue microarrays: high throughput and low cost available for pathologists. Rev. Bras. Patol. Med. Trop., v.43, p.55-60, 2007.

BUBENDORF, L.; NOCITO, A.; MOCH, H. et al. Tissue microarray (TMA) technology: miniaturized pathology archives for highthroughput in situ studies. J. Pathol., v.195, p.7279, 2001.

CALAZANS, S.G.; RODIGHERI, S.M.; FERNANDES, S.C. et al. Imunorreatividade da p53 associada à ausência de mutações no gene P53 em linfomas caninos. Ciênc. Rural., v.40, p.1444-1447, 2010.

COWELL, R.L.; TYLER, R.D.; KOTH, J.H.M. et al. Diagnostic cytology and hematology of the dog and cat. Maryland: Mosby Elsevier, 2008. p.475.

DUNN, G.P.; OLD, L.J.; SCHREIBER, R.D. The three Es of cancer immunoediting. Annu. Rev. Immunol., v.22, p.329-360, 2004.

FARIA, M.H.G.; RABENHORST, S.H.B. Impacto do oncogene C-MYC no câncer. Rev. Bras. Canceriol., v.52, p.165-171, 2006. 
FLORÉZ, M.M.; PEDRAZA, F.; GRANDI, F. et al. Cytological subtypes of canine transmissible venereal tumor. Vet. Clin. Pathol., v.41, p.3-5, 2012.

FONSECA, L.S.; MOTA, L.S.L.S.; CORDEL, M.M. et al. Spontaneous canine transmissible venereal tumor: association between different phenotypes and the insertion LINE-1/C-MYC. Rev. Colomb. Ciênc. Реcu, v.25, p.402-408, 2012.

GASPAR, L.F.J.; FERREIRA, I.; COLODEL, M.M. et al. Spontaneous canine transmissible venereal tumor: cell morphology and influence on P-glycoprotein expression. Turk. J. Vet. Anim. Sci., v.34, p.447-454, 2010.

GONZALEZ, C.M.; GRIFFEY, S.M.; NAYDAN, D.K. et al. Canine transmissible venerealtumor: a morphological and immunoistochemical study of 11 tumors in growth phase and during regression after chemotherapy. J. Comp. Pathol., v.122, p.241-248, 2000.

KONONEN, J.; BUBENDORF, L.; KALLIONIEMI, A. et al. Tissue microarrays for high-throughput molecular profiling tumor of specimens. Nat. Med., v.4, p.844-847, 1998.

LIMA, C.R.O.; RABELO, R.E.; VULCANI, V.A.S. et al. P53 Gene: Major mutations in neoplasia and anticancer gene therapy. Ciênc. Rural, v.42, p.845-853, 2012.

LUTZ, W.; LEON, J.; EILERS, M. Contributions of myc to tumorigenesis. Acta Bioch. Bioph., v.1602, p.61-71, 2002.

MATOS, L.L.; STABENOW, E.; TAVARES, M.R. et al. Immunohistochemistry quantification by a digital computer-assisted method compared to semiquantitative analysis. Clinics, v.61, p.417424, 2006.

MORO, J.V.; TINUCCI-COSTA, M.; SILVEIRA, A.C.T. et al. Reactivity of p53 protein canine transmissible venereal tumor. Arq. Bras. Med. Vet. Zootec., v.62, p.318-323, 2010.
MURCHISON, E.P. Clonally transmissible cancers in dogs and Tasmanian devils. Oncogene, v.27, p.19-30, 2009.

O’NEILL, I.D. Concise review: transmissible animal tumors as models of the cancer stem-cell process. CancerStem Cells, v.29, p.1909-1914, 2011.

PARK, M.S.; KIM, Y.; KANG, M.S. et al. Disseminated transmissible venereal tumor in a dog. J. Vet. Diag. Invest., v.18, p.130-133, 2006.

PELENGARIS, S.; KAN, M. The many faces of C-MYC. Arch. Bioch. Biophy., v.416, 129-136, 2003.

SÁNCHEZ-SERVÍN, A.; MARTINÉZ, S.; CÓRDOVA-ALARCON, E.; FAJARDO, R. P53 Polymorphisms allow for genetic sub-grouping of the canine transmissible venereal tumor. $J$. Vet. Sci., v.10, p.353-355, 2009.

SANTOS, F.G.A.; VASCONCELOS, A.C.; NUNES, J.E.S. et al. Apoptosis in the transplanted canine transmissible venereal tumor during growth and regression phases. Arq. Bras. Med. Vet. Zootec., v.60, p.607-612, 2008.

SPIN, J.S.; FONSECA, L.S.; MOTA, L.S.L.S. et al. Detecção molecular do rearranjo LINE-1/CMYC em tumores venéreos transmissíveis caninos espontâneos. Clín. Vet., v.15, p.89, 2010.

STOCKMANN, D.; FERRARI, H.F.; ANDRADE, A.L. et al. Canine transmissible venereal tumors: aspects related to programmed cell death. Braz. J. Vet. Pathol., v.4, p.65-75, 2011.

TROMPIERI-SILVEIRA, A.C.; GERARDI, D.; MOURO, J.V. et al. Immunohistochemical expression of $\mathrm{B}$ and T-lymphocytes and TGF- $\beta$ in experimentally transplanted canine venereal tumor. Ciênc. Rural, v.39, p.1148-1154, 2009. 